\title{
Refuge
}

Canada's Journal on Refugees

revue canadienne sur les réfugiés

\section{Elusive Jannah: The Somali Diaspora and Borderless Muslim Identity, by Cawo M. Abdi}

\section{Rutendo Hadebe}

Volume 34, Number 2, 2018

URI: https://id.erudit.org/iderudit/1055587ar

DOI: https://doi.org/10.7202/1055587ar

See table of contents

Publisher(s)

Centre for Refugee Studies, York University

ISSN

0229-5113 (print)

1920-7336 (digital)

Explore this journal

Cite this review

Hadebe, R. (2018). Review of [Elusive Jannah: The Somali Diaspora and Borderless Muslim Identity, by Cawo M. Abdi]. Refuge, 34(2), 153-154.

https://doi.org/10.7202/1055587ar 
gendered differences, particularly in shifting livelihood responsibilities, more expansive educational opportunities, and new cultural landscapes.

Overall, Belonging and Transnational Refugee Settlement should be applauded for emphasizing the need to recognize the complexity of refugee lives, and to rethink the dominant assumptions that so often render refugees through singular frames of victimhood. With its accessible theoretical frameworks and diverse case study analyses, Belonging and Transnational Refugee Settlement is highly recommended for undergraduates, graduate students, and practitioners who are interested in refugee settlement from fields of migration studies, sociology, social work, health, policy, and other applied fields.

Georgina Ramsay is an assistant professor of anthropology at University of Delaware and can be reached at gramsay@udel .edu.

\section{Elusive Jannah: The Somali Diaspora and Borderless Muslim Identity \\ $\sim$ \\ Cawo M. Abdi \\ Minneapolis: University of Minnesota Press, 2015, 289 pp.}

I n Elusive Jannah: The Somali Diaspora and Borderless Muslim Identity, Cawo Abdi gives a nuanced account of the lives of the Somali diaspora in three key locations: the United Arab Emirates (UAE), South Africa, and the United States. The book is based on three years of rigorous ethnographic enquiry and meticulous documentation, including 162 interviews and ten focus groups with members of the Somali diaspora. Abdi, herself a Somali-born academic, who arrived in Canada as an asylum seeker, acknowledges the resourcefulness of her positionality in navigating Somali communities with whose culture and predicament she could identify. The book contributes detailed new knowledge and ways of thinking to the refugee and migration literature. Throughout, the book engages with identity, belonging, residency, and integration. A Muslim identity is continually interrogated and juxtaposed with locally encountered identities.

The publication of Abdi's work coincides with the escalation of migration discourses as a priority in foreign policy debates on obligations to asylum seekers and refugees from failed states, such as Somalia. Within these discussions, the implications for the receiving community in national resource sharing (such as welfare) and cultural assimilation or integration have taken centre stage. The three research sites show the importance of "place" in how integration experiences unfold.

The book is divided into six chapters: an introduction, a conclusion, and four chapters. The book launches with a chapter entitled, "The Genesis of Contemporary Somali Migrations." Here Abdi describes the Somali experience and seamlessly integrates the role and history of Dadaab (a collective of three refugee camps in northeastern Kenya) as the launch pad into the pursuit of the Jannah (Arabic for paradise). The volume provides intriguing detail about Somalia's history with democracy, dictatorship, violence, and crisis, allowing the reader to understand the breakdown that led to the current era of exodus, as well as previous large population movements, including the exoduses to the UAE in the 1970 s in the wake of Somalia-Ethiopia war.

The first case study is set in the UAE, an absolute monarchy that remains a non-signatory to the 1951 UN Convention on Refugees (among other international human rights documents). Studying Somali experiences in the UAE is significant, because this setting and how it meets its own need for foreign labour while simultaneously circumventing the liberal human rights legal regime is distinctive. Importantly, the UAE doesn't provide for pathways to citizenship for migrants. Somali interviewees frame the UAE as an easy country to navigate. They described benefiting from the favouritism the Emirati showed them due to a shared Arab identity. In a county made up of 80 per cent foreign labour, with no integration system, this hierarchy of differences works in Somalis' favour. This part of the book provides rare insight into the realities and politics of migration outside a liberal democracy setting.

The second case study is South Africa, a democratic republic in its infancy. This setting conjures questions of migration policy in a post-apartheid context of pervasive racism and extreme inequality. The case studies of Somalis residing in Johannesburg and Cape Town are interwoven with the realities of transforming South Africa and the tightrope the state walks in attempting to simultaneously meet 
national and international obligations vis-à-vis migrants. The South African narratives provide a window into the Muslim brotherhood by unpacking a fraternity that unites the Somalis with South African Indian Muslims. Although the South African government's commitment to meet its obligation to Somali refugees surpasses all its regional neighbours, the country remains a liminal space; a stepping stone to the United States, the imagined Jannah. The word Jannah appears several times in the text to capture Somalis' imaginaries of an anticipated paradisiacal destination. This optimistic view of South Africa is complicated by incidences of xenophobia and insecurity, and, in some cases, violence, perpetrated by poor black members of the neighbourhoods in which Somalis earn their livelihoods.

The final part of the book focuses on Somalis in the United States. Here Abdi juxtaposes the imagined glorified portrayals of day-to-day North America with Somalis' challenging encounters with U.S. immigration policy. The U.S. accounts are fraught with contradictions and deviations from what is imagined to be the reality that awaits the Somali diaspora, or what Abdi calls Elusive Jannah or elusive paradise. The U.S. chapter highlights both the culture shock and incompatibility between American and Somali culture. Here Abdi's objective to bring to the fore issues of settlement and integration is most illuminated, and she makes a case for the need for more efficient and inclusive strategy-designing methods to meet the humanitarian obligation to provide home to Somalis in distress.

Overall this book is a poignant compilation of narratives collected between 2008 and 2012; however, the book's time frame misses a key shift in the global construction of Somali identity in the wake of Al-Shabaab's meteoric rise as an international terrorist group in East Africa. Evidenced from 2013 onwards, a study that incorporates this development would add a textured layer to an already insightful piece of work.

Taken as a whole, this book provides a humanized account of what is generally abstracted in foreign policy and international law debates on refugees, security vetting, repatriation, visa restrictions, welfare benefits, and related issues that fall under the migration regime. In the book, each of these issues is punctuated by real human experiences, anxieties, and insecurities and brings to the fore the possibility of migration policy formulation through analysis of non-reductive refugees' voices.

Rutendo Hadebe is a PhD fellow at the Centre for Humanities Research, University of the Western Cape, South Africa. She can be reached at rutendoh7@gmail.com.

\title{
Gender, Violence, Refugees
}

\author{
n \\ Edited by Susanne Buckley-Zistel and Ulrike Krause \\ New York: Berghahn, 2017, 292 pp.
}

$\mathrm{T}$ The institutional conditions and socio-cultural dynamics that give rise to sexual and gender-based violence are analyzed in Gender, Violence, Refugees by focusing on a global set of case studies. Drawing from the experiences of refugees fleeing conflicts and persecution in Burundi, Congo, Syria, Sudan, and Western Burma, among others, the authors in this edited collection explore conceptual frameworks for understanding violence as it is differentially experienced by refugees; the role of "host" nations in determining experiences of refuge; and the ways that gender understood by both refugees and "host" societies shapes experiences of violence, settlement, and post-conflict return.

One of the most important contributions of the volume is the challenge to understandings of the relationship between refugee processes and sexual violence. This challenge is presented in numerous chapters throughout the volume but most notably in those by Turner and Olivius. Turner takes issue with the "orientalist" assumptions used to justify moral panic vis-à-vis migrants in public discourse. He challenges an un-interrogated, unsubstantiated claim in some refugee studies scholarship that "displacement causes social and moral chaos" where male sexuality runs "amok" (54). Olivius similarly points to the problems in scholarship and international community interventions that locate violence against women in the cultural fabric of refugee communities. Her work suggests that, in practice, the lack of culturally sensitive approaches to the problem of violence against women "denies refugees a role as agents in the transformation of their own communities" (73). Krause's own chapter in the volume calls for focused attention on the problem of sexual violence and refuge that takes into account the sites of its occurrence in "conflict, flight and protected encampment" (181) but also understands that violence in refuge takes place in a broader continuum of violence.

A number of chapters focused on the recent European response to forced migration carefully examine the ways that 